Article

\title{
Supplementary LED Interlighting Improves Yield and Precocity of Greenhouse Tomatoes in the Mediterranean
}

\author{
Ivan Paucek ${ }^{1}$, Giuseppina Pennisi ${ }^{1, * \mathbb{D}}$, Alessandro Pistillo ${ }^{1}$, Elisa Appolloni ${ }^{1}$, \\ Andrea Crepaldi ${ }^{2}$, Barbara Calegari ${ }^{3}$, Francesco Spinelli ${ }^{1}{ }^{1}$, Antonio Cellini ${ }^{1}{ }^{1}$, \\ Xavier Gabarrell ${ }^{4}$ (D) Francesco Orsini ${ }^{1}(\mathbb{D})$ and Giorgio Gianquinto ${ }^{1}$ (D) \\ 1 DISTAL-Department of Agricultural and Food Sciences, Alma Mater Studiorum-University of Bologna, \\ viale Fanin 44, 40127 Bologna, Italy; ivan.paucekpagan@studio.unibo.it (I.P.); \\ alessandro.pistillo@studio.unibo.it (A.P.); elisa.appolloni3@unibo.it (E.A.); francesco.spinelli3@unibo.it (F.S.); \\ antonio.cellini2@unibo.it (A.C.); f.orsini@unibo.it (F.O.); giorgio.gianquinto@unibo.it (G.G.) \\ 2 Flytech srl, Via dell'Artigianato, 65, 32016 Alpago, Belluno, Italy; andrea.crepaldi@flytech.it \\ 3 I-POM Pellerossa, Via Cantapoiana, 12, 40054 Mezzolara di Budrio, Bologna, Italy; b.calegari@ipom.biz \\ 4 Sostenipra Research Group (SGR 01412), Institut de Ciència i Tecnologia \\ Ambientals (ICTA-UAB) (MDM-2015-0552), Z Building, Universitat Autònoma de Barcelona (UAB), \\ Campus UAB, Bellaterra, 08193 Barcelona, Spain; Xavier.Gabarrell@uab.cat \\ * Correspondence: giuseppina.pennisi@unibo.it
}

Received: 7 June 2020; Accepted: 9 July 2020; Published: 12 July 2020

\begin{abstract}
In Northern Europe, the use of light-emitting diodes (LEDs) is widely adopted in protected horticulture, enabling to enhance plant growth by ensuring needed radiative fluxes throughout seasons. Contrarily, the use of artificial lighting in Mediterranean greenhouse still finds limited applications. In this study, the effects of supplemental LED interlighting on vegetative development, fruit growth, yield, and fruit quality of high-wire tomato plants (Solanum lycopersicum L. cv. 'Siranzo') during spring and summer season were addressed in a hydroponic greenhouse in Italy. Plants were either grown under natural solar radiation (control), or by adding supplemental LED interlighting. LED treatment featured red (R) and blue (B) light (RB ratio of 3) and a photosynthetic photon flux density of $170 \mu \mathrm{mol} \mathrm{m} \mathrm{m}^{-2} \mathrm{~s}^{-1}$ for $16 \mathrm{~h} \mathrm{~d}^{-1}$. Supplemental LED interlighting enhanced yield as a result of increased fruit weight and dimension. While no effects on soluble solids content and fruit color at harvesting were observed, supplemental LED interlighting accelerated ripening by one week in spring and two weeks in summer and this also resulted in increased cumulated productivity $(+16 \%)$ as compared to control treatment. Overall, supplemental LED interlighting can represent a feasible technology for tomato greenhouse production also in the Mediterranean region.
\end{abstract}

Keywords: Solanum lycopersicum; light emitting diodes (LEDs); photosynthetic photon flux density (PPFD); supplemental interlighting; yield; greenhouse cultivation

\section{Introduction}

Tomato (Solanum lycopersicum L.) is one of the most important vegetable crops produced worldwide, especially in the Mediterranean area where it represents a major component of the traditional cuisine. Tomato global production has been increasing along the past years up to 182 million tons in 2018 [1]. This increment is related to an expansion of the greenhouse vegetable industry (occurred since the mid-1990s both in Europe and North America) and the innovation in cultivation technologies (e.g., grafting, hydroponics), which have resulted in yield increases [2,3]. 
Recently, among developed economies, the use of high-tech greenhouse facilities for vegetable crop cultivation is spreading, allowing off-season production, higher yields, better input management and control, improvement of the product quality and higher marketable value [4]. However, if modern greenhouse technologies offer the possibility to increase plant density as compared with open field cultivation, drawbacks associated with improper light exposure and mutual shading may also occur [5,6]. Accordingly, light in tomato greenhouse cultivation could become a limiting factor, especially for what concerns lower portion of the canopy [7-11]. Moreover, solar light interception can be limiting for the whole plant during wintertime, while the quantification of yield reduction possibly caused by frequent cloudy or rainy days in other seasons still remains unclear [10].

Recent research mentioned several lighting technologies (e.g., fluorescent lamps, high-pressure sodium (HPS) lamps, metal halide lamps, or light emitting diodes (LED) lamps) as a solution to enhance crop productivity in case of limited light conditions [7-9,12-14]. In the past, HPS lamps have been the most commonly utilized for plant-growth applications in greenhouses [15], despite their intrinsic features resulting in several drawbacks (e.g., low electrical efficiency, non-uniform spectral distribution, and large radiant heat) [16]. More recently, the evolution of LED lighting technologies enabled to achieve wavelength specificity, low power consumption, long lifetime, and cool emitting surface [8], which determine a greater suitability especially in the case of interlighting application (with the lighting source placed within plant canopy) [10].

This study investigates the effects of supplemental LED interlighting lamps on plant morphologic development, fruit yield, and fruit quality, applied in a high-wire tomato greenhouse located in Northern Italy. The research objective was to evaluate the feasibility of optimized supplemental lighting technology for tomato crop production in the Mediterranean region.

\section{Materials and Methods}

\subsection{Plant Material and Growing Conditions}

The experiment took place in the high-wire hydroponic greenhouse of iPOM Pellerossa s.r.l, located at Mezzolara di Budrio, Bologna, Italy $\left(44^{\circ} 34^{\prime} 49^{\prime \prime} \mathrm{N}, 11^{\circ} 31^{\prime} 54^{\prime \prime} \mathrm{E}\right)$. The greenhouse structure is covered with a MultiEVA film, and features natural ventilation roof, lateral openings and horizontal fan systems for air circulation. Tomato seedlings (Solanum lycopersicum L. cv. 'Siranzo'; Rijk Zwaan ${ }^{\circledR}$ ) germinated in rock wool cubes $\left(100 \mathrm{~mm} \times 100 \mathrm{~mm} \times 65 \mathrm{~mm}\right.$ ) were transferred into rock wool slabs (Grodan ${ }^{\circledR}$ Vital, Roermond, Netherlands) on 3 January 2019 and experiment was closed on 23 September 2019. Plants were cultivated as two-stem V-system, with a planting density of 3.1 stems $\mathrm{m}^{-2}$. Maximum and minimum average daily temperatures and relative humidity, as well as external daily cumulated solar radiation were monitored by the greenhouse environmental control system during the whole growing cycle. The greenhouse uses hot water residual flow coming from an adjacent biogas plant to maintain a proper temperature in the coldest months.

A computer-controlled drip-irrigation system with closed cycle was used to fertigate plants. The fertigation consisted on a complete nutrient solution, containing similar rates of macronutrients, micronutrients and acids along the growing cycle (Table 1). Chemical characteristics of the nutrient solution were constantly monitored and adjusted to maintain a $\mathrm{pH}$ of 6.0 and an electrical conductivity (EC) of $2.6 \mathrm{dS} \mathrm{m}^{-1}$.

\subsection{Light Treatment and Experimental Design}

Two lighting regimes (control and LED) were applied. Control plants were cultivated under natural lighting conditions, while LED treated plants also received supplemental light provided by LED interlighting lamps (Flygrow Interlight, Flytech LED Technology ${ }^{\circledR}$, Belluno, Italy), starting from 26 February 2019.

LED interlighting system consisted of lamps featuring red ( $R$, peak wavelength: $666 \mathrm{~nm}$; band width at half peak height: $24 \mathrm{~nm}$ ) and blue (B, peak wavelength: $462 \mathrm{~nm}$; band width at half peak 
height: $27 \mathrm{~nm}$ ) diodes, emitting a spectrum characterized by a red:blue (RB) ratio of $3[17,18]$ and supplying a photosynthetic photon flux density (PPFD) of $170 \mu \mathrm{mol} \mathrm{m}{ }^{-2} \mathrm{~s}^{-1}$ at $30 \mathrm{~cm}$ of distance from the lamps for $16 \mathrm{~h} \mathrm{~d}^{-1}$ (8:00-00:00). Lamps were placed at $1.2 \mathrm{~m}$ and $1.5 \mathrm{~m}$ height from the rock wool slabs, within plants canopy (Figure 1) at a distance of $30 \mathrm{~cm}$ from the stem.

Table 1. Nutrient solution composition adopted in iPOM greenhouse during spring and summer season.

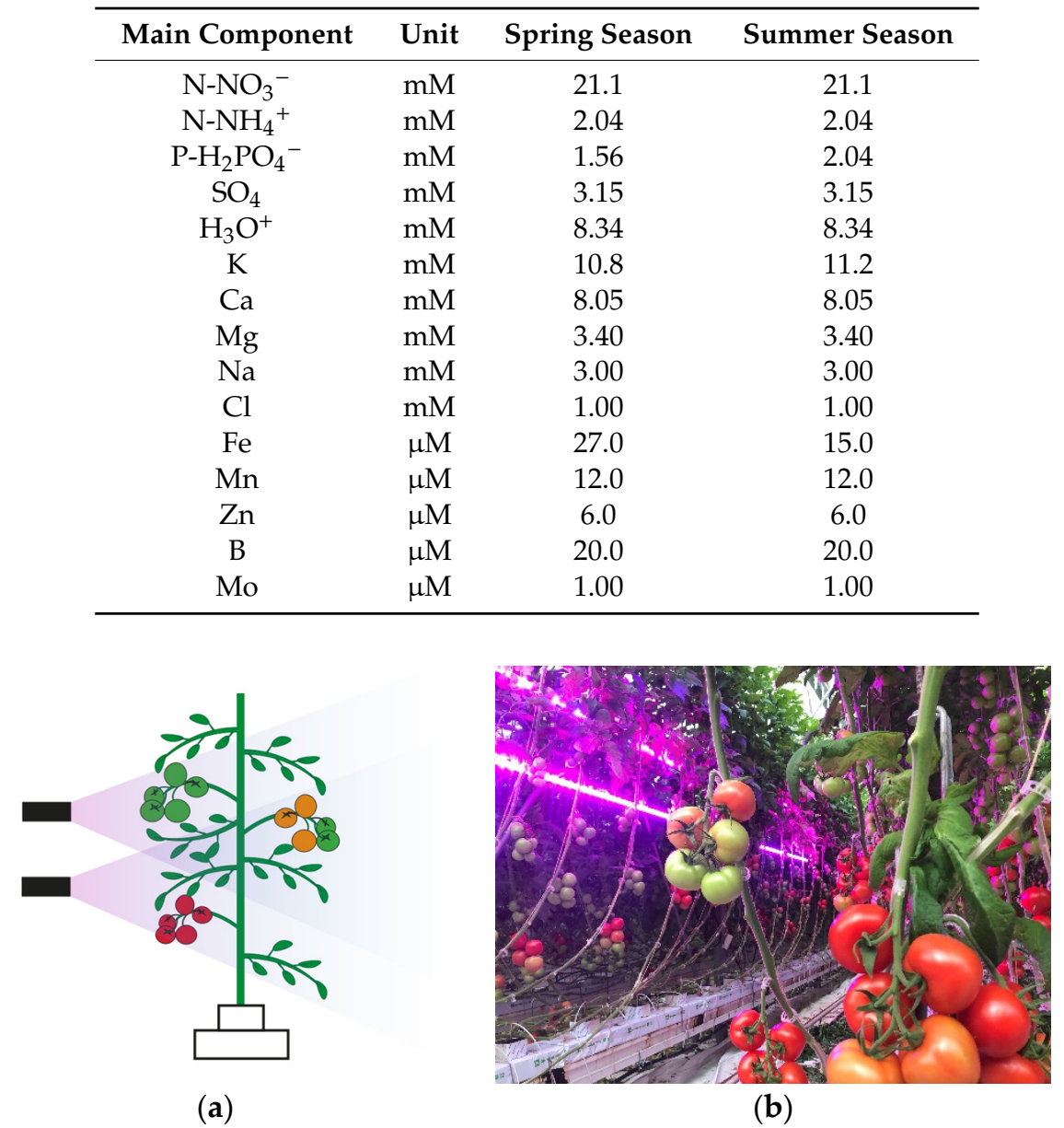

Figure 1. Supplemental light-emitting diode (LED) interlighting arrangement within plant canopy. (a) Graphical representation and (b) side-view of the illuminated treatment on 3 May 2019 (Photo: I. Paucek).

A strip-block design was used with three replications containing 5 plants per replicate (monitoring in total 15 plants per treatment). The experiment was divided in two seasons: from 11 March 2019 until 21 June 2019 (spring season) and from 22 June 2019 until 23 September 2019 (summer season).

\subsection{Vegetative and Fruit Growth Measurements}

Internode length and stem diameter were measured under the first ripening fruit truss from the base. Collar diameter was also monitored at $1 \mathrm{~cm}$ from the rock wool cube surface for the whole plant cycle. Leaf length (including petiole length) and leaf width were measured at the top leaflet of the branch on three leaves per plant.

Fruit dimensions (transversal and longitudinal diameter) were monitored on three tomatoes of the same cluster of each plant by using a manual Vernier caliper. Measures were taken once per week until harvest time. At the same time, fruit color was evaluated according to fruit growth/maturation phase (Figure 2). 


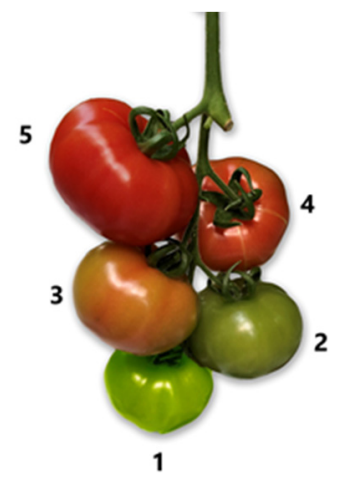

Figure 2. Tomato cluster with fruits in different growth/maturation phases according to external coloration: (1) green (fruit growth), (2) dark green (green, breaker ripeness classes), (3) light orange (turning, pink ripeness classes), (4) dark orange (light-red ripeness class), and (5) red (red ripeness class).

Vegetative and fruit growth measurements were performed in two periods: from 11 March 2019 until 6 May 2019 (spring season) and from 1 July 2019 until 22 August 2019 (summer season) once per week. Leaf dimensions were only measured during spring.

\subsection{Physiological and Quality Measurements}

Physiological and quality measurements were performed on 12 April 2019. Relative chlorophyll content of leaves was evaluated by using an N-Tester (Yara N-Tester ${ }^{\mathrm{TM}}$, Yara, Oslo, Norway) on the youngest fully developed leaves of three selected plants per replicate per treatment. Stomatal conductance and leaf temperature were measured by using respectively a leaf porometer (AP4 Porometer, Delta-T Devices Ltd., Cambridge, England) and an infrared thermometer (Fluke 66 Handheld Infrared Thermometer, Fluke, Everett, Washington, USA) on a completely expanded leaf at mid-height within the canopy and within $50 \mathrm{~cm}$ from lamps in the LED treatments, on three selected plants per replicate per treatment.

Fruit soluble solids content was performed by using a digital refractometer (Atago ${ }^{\circledR}$, Tokyo, Japan). In addition, 8 fruits per treatment were selected for CIE Lab color space analysis, where L component represents the lightness from black (0) to white (100), a component ranges from green (-) to red $(+)$, and b component from blue $(-)$ to yellow $(+)$.

\subsection{Post-Harvest Measurements}

From 25 March 2019 to 23 September 2019 fruit clusters were harvested once per week, on an average of 23 clusters per plant. A digital scale was used to determine the fresh weight of the cluster after harvesting. Number of clusters and number of fruits per cluster were counted for each plant. The average fresh weight of an individual fruit was calculated by dividing the cluster fresh weight by the number of fruits. The total fresh mass of fruits produced by each plant was calculated by summing the clusters weight.

\subsection{Statistical Analysis}

Data were collected on 5 plants per replicate per treatment (unless otherwise stated). Before the analysis, all data were checked for normality (Shapiro-Wilk test) and homogeneity of the variance (Levene's test). Microsoft Excel software and R statistical software version 3.3.2 (packages "emmeans" and "car") were employed for the analysis of the experimental data. One-way ANOVA was used for the statistical analysis. 


\section{Results and Discussion}

\subsection{Environmental Conditions during the Experiment}

The potentialities for crop yield enhancement through accurate environmental control has driven the rapid evolution of greenhouse cultivation in the last decades, also in the Mediterranean basin [3]. One of the most important microclimate parameters affecting tomato production and quality is air temperature [19]. Jun et al. [20] reported that the best temperature regime for net photosynthesis on greenhouse-grown tomatoes is $28 / 20^{\circ} \mathrm{C}$ (day/night), while higher or lower temperatures can negatively affect fruit set [21]. In the current research, minimum and maximum average air temperatures inside the greenhouse were maintained between 16.5 and $23.4{ }^{\circ} \mathrm{C}$ (spring) and 20.9 and $26.8^{\circ} \mathrm{C}$ (summer) (Figure 3a). However, in 30 days of spring and 70 days of summer, a maximum temperature above $30{ }^{\circ} \mathrm{C}$ was also reached inside the greenhouse (Figure 3a). Despite most tomato cultivars perform at their best under relative humidity (RH) ranging between 50 and 70\% [22], maximum $\mathrm{RH}$ reached 96 and 99\% during the spring and summer, respectively (Figure 3b). Average RH on the other hand resulted quite stable across seasons and sufficiently low to allow a stable plant growth (55\%). Also, total solar radiation can directly affect the growth of tomato fruit [8]. During the considered growing cycle, the average external cumulated solar radiation was 1825 and $2064 \mathrm{~J} \mathrm{~cm}^{-2}$ day $^{-1}$ for spring and summer season respectively (Figure 3c). However, light transmissivity within the greenhouse can be limited by $20-30 \%$ as a result of structure and covering interference, in addition to the reduction determined by plant canopy shading [23]. Specific limitations in greenhouses have solicited measures to improve solar radiation capture, since well-designed greenhouses can determine a better light transmission than traditional ones [3]. Nonetheless, solar radiation can vary daily, affecting thereby the final yield of tomato plants [8].

\subsection{Plant Vegetative Growth in Response to Supplementary Lighting}

Several studies addressed the relations occurring between light availability, plant productivity, and plant canopy architecture. Light availability influences plant photosynthesis, which directly affects biomass production [24]. This is particularly evident in highly dense plant production systems such as those of greenhouses, where a $1 \%$ reduction of daily light integral (DLI) may cause $1 \%$ reduction in fruit vegetable yields (e.g., cucumber, tomato, and sweet pepper) [25]. Concurrently, according to Beer-Lambert's law, plant photosynthetic rate depends on the amount of light intercepted by canopy layers, which is function of leaf area index (LAI) and light extinction coefficient $(k)$ that highly depend on canopy architectural traits (e.g., internode length, stem diameter, and leaf dimension) [26]. Light availability can be a limiting factor for plant development in highly dense greenhouse tomato cultivation. Accordingly, the effects of supplemental interlighting systems on canopy architectural traits have been subject of several researches. In a greenhouse grown tomato [9], no effects on crop architecture (stem height, stem diameter, and leaf length) were observed when solar radiation was integrated with supplemental LED interlighting emitting $80 \mu \mathrm{mol} \mathrm{m}{ }^{-2} \mathrm{~s}^{-1}$ at $30 \mathrm{~cm}$. Contrarily, when tomato plants were treated with a supplemental LED interlighting system (with lamps emitting $165 \mu \mathrm{mol} \mathrm{m}{ }^{-2} \mathrm{~s}^{-1}$ at $10 \mathrm{~cm}$ for $12 \mathrm{~h} \mathrm{~d}^{-1}$ ), a greater stem diameter and a shorter internode length as compared to plants grown under natural solar light in both summer and winter seasons were observed [10]. In another study by Tewolde et al. [24], plants grown under natural light were compared to plants undergoing supplemental LED interlighting (red and blue diodes featuring RB $=4$ and PPFD of $220 \mu \mathrm{mol} \mathrm{m}{ }^{-2} \mathrm{~s}^{-1}$ ), against two different cloudy cover simulations obtained using a shading cloth for $40 \%$ and $60 \%$ of the cycle. While internode length was not affected by the different lighting regimes, stem diameter of plants grown under both shading simulations was lower as compared to control plants [24]. However, the application of supplemental LED interlighting on shaded plants showed a positive effect on stem diameter growth, obtaining similar results as compared to plants grown under control non-shaded conditions [24]. 


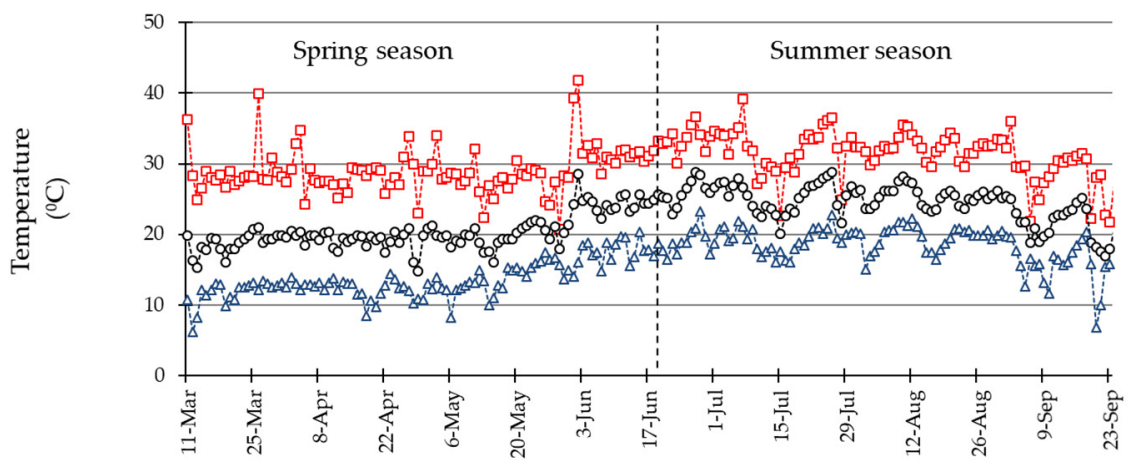

(a)

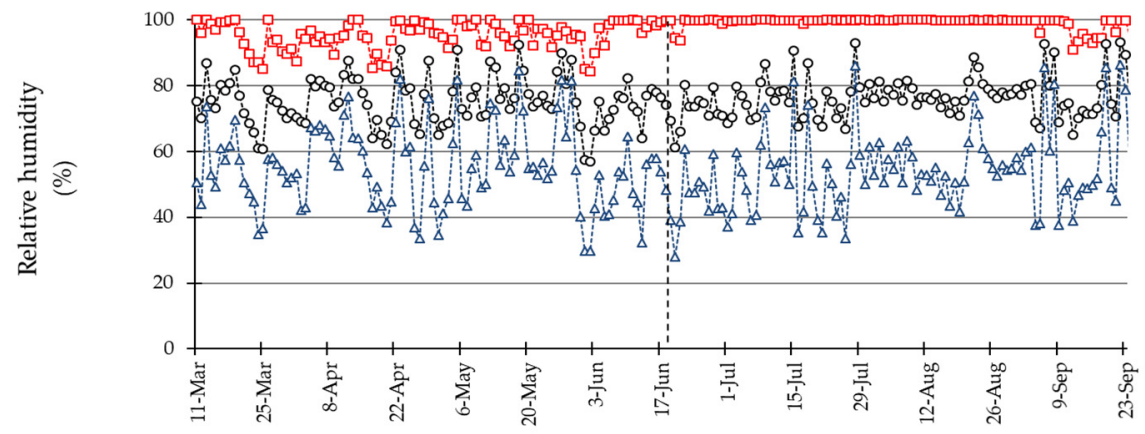

(b)

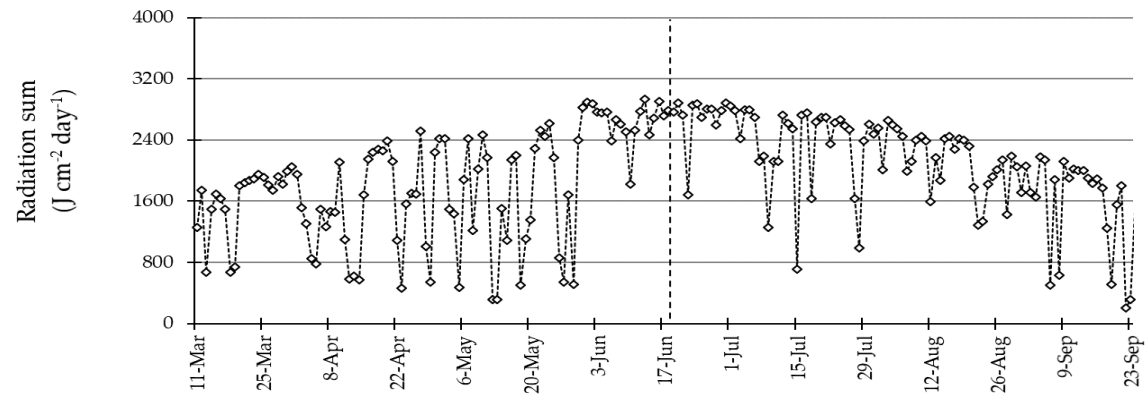

(c)

Figure 3. Environmental parameters at iPOM greenhouse. (a) Daily maximum (red squares), minimum (blue triangles), and average (black circles) temperatures; (b) daily maximum (red squares), minimum (blue triangles), and average (black circles) relative humidity; and (c) external (outdoor) daily radiation sum during growing cycle.

In the present research, internode length and stem diameter were measured both in spring and summer season (Figure 4). Supplemental LED interlighting influenced internode length, with a reduction on LED treated plants by $6 \%$ in spring and $12 \%$ in summer as compared to control plants (Figure $4 a, c)$. This dwarfing effect of LED supplemental lighting on internode length was already observed on tomato and cucumber plants in previous researches, as a result of increased light distribution within plant canopy enabling a greater light absorption $[10,27,28]$. Also stem diameter was influenced by supplemental LED interlighting in both spring and summer season, with greater values ( $+8 \%$ and $+17 \%$, respectively, in the spring and summer season) in LED treated plants as compared to control plants (Figure $4 \mathrm{~b}, \mathrm{~d}$ ). Similarly, collar diameter of LED treated plants was enhanced by $+23 \%$ and $+25 \%$ in the spring and summer season, respectively, as compared to control plants (data not shown). Furthermore, similarly to findings of previous studies [9-11,24] no statistically significant 
differences among LED treated and control plants were detected for leaf width (mean value of $11.7 \mathrm{~cm}$ ) and leaf length (mean value of $24 \mathrm{~cm}$ ) in the present research (data not shown).

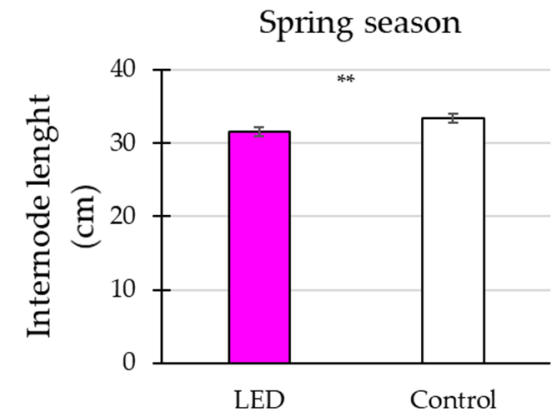

(a)

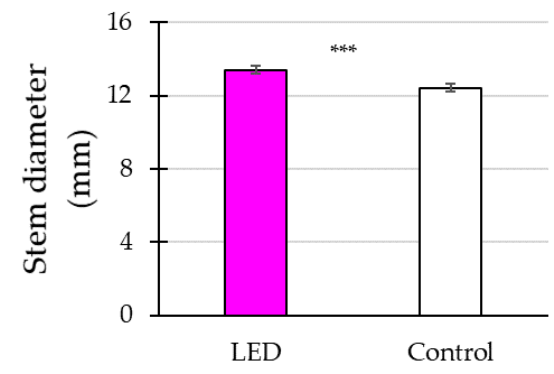

(b)

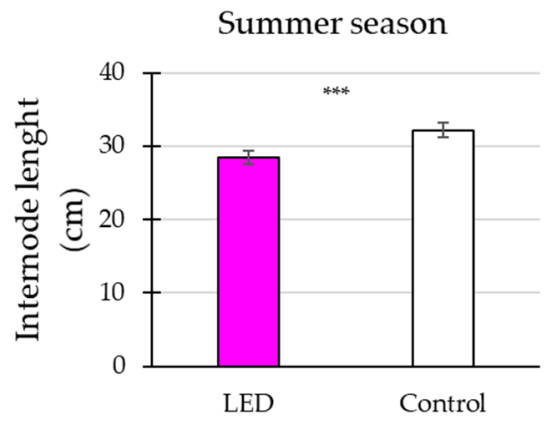

(c)

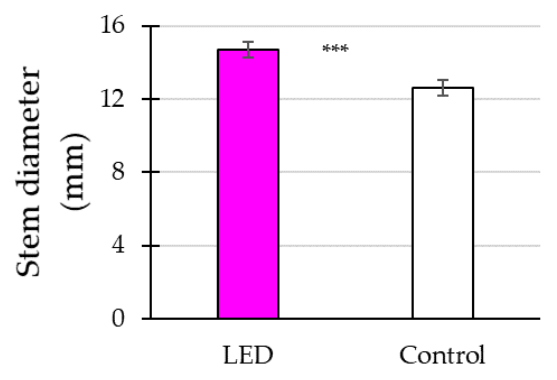

(d)

Figure 4. Effect of lighting regime on internode length $(\mathbf{a}, \mathbf{c})$ and stem diameter $(\mathbf{b}, \mathbf{d})$ during spring $(\mathbf{a}, \mathbf{b})$ and summer $(\mathbf{c}, \mathbf{d})$ season. Symbols $\left(^{* *}\right)$ indicate significant differences at $p \leq 0.01$, or $p \leq 0.001\left(^{* * *}\right)$.

\subsection{LED Interlighting Improves Leaf Gas Exchanges and Alters Leaf Temperature}

The effects of supplemental LED interlighting on specific physiological parameters of tomato crop have been studied in the last decade. Gajc-Wolska et al. [29] compared high-wire tomatoes grown under natural light and supplemental LED treatment (overhead lamps emitting $100 \mu \mathrm{mol} \mathrm{m}^{-2} \mathrm{~s}^{-1}$ at $1 \mathrm{~m}$ for $16 \mathrm{~h} \mathrm{~d}^{-1}$ ), obtaining greater values for photosynthesis, transpiration, stomatal conductance, and leaf chlorophyll content in plants exposed to supplemental artificial light. In another research [11], the effects of supplemental inner canopy LED modules (emitting $200 \mu \mathrm{mol} \mathrm{m}{ }^{-2} \mathrm{~s}^{-1}$ at $10 \mathrm{~cm}$ for $16 \mathrm{~h} \mathrm{~d}^{-1}$ ) were also compared to a sole-solar radiation treatment, resulting in a significant increase of net photosynthesis, stomatal conductance and transpiration in plants under LEDs, although no concurrent changes in leaf chlorophyll content were observed.

In the present research, higher leaf chlorophyll content estimated by chlorophyll meter $(+15.5 \%)$ was found in plants cultivated with supplemental LED light (Table 2). Similarly, the addition of supplemental LED interlighting featuring different percentages of red, blue, and far red diodes resulted in an average increase of $11 \%$ in leaf chlorophyll content as compared to plants grown under sole solar radiation [30]. Accordingly, red and blue LEDs were suggested to alter both anatomical and morphological leaf parameters, while also promoting chloroplast development [31]. Both stomatal conductance and leaf temperature resulted affected by lighting treatments (Table 2). Accordingly, stomatal conductance in LED treated plants resulted approximately three-times higher as compared to control plants (Table 2). Under control conditions, the limited radiation within the canopy may have induced stomatal closure and decreased photosynthetic activity [11]. Contrarily, supplemental LED interlighting fosters $\mathrm{CO}_{2}$ uptake and, consequently, photosynthesis by promoting stomatal conductance, as previously observed in tomato [11] and cucumber [32]. When transpiration rate is higher, a lower leaf temperature is generally experienced, since thermal energy required for evaporation is subtracted from the leaf surface [33]. However, in the present research, higher stomatal conductance of LED 
treated plants was accompanied by a higher leaf temperature as compared with control plants (Table 2), possibly in response to the heat released by LED lamps, which can ultimately alter the environmental temperature around mid-canopy as a consequence of direct irradiance [10]. The increased temperature at canopy level in the observed ranges (e.g., from 16.6 to $18^{\circ} \mathrm{C}$, Table 2) during spring could also have been beneficial to the plants, whereas it should be further investigated whether heat released by lamps during warmer months may eventually affect plant performances.

Table 2. Effect of lighting regime on leaf chlorophyll content, stomatal conductance, and leaf temperature in spring season.

\begin{tabular}{ccc}
\hline & LED & Control \\
\hline Leaf chlorophyll content $($ N-tester value) & 505.2 & 437.4 \\
Stomatal conductance $\left(\mathrm{mmol} \mathrm{m}^{-2} \mathrm{~s}^{-1}\right)$ & 367.1 & \multicolumn{2}{c}{126.8} \\
Leaf temperature $\left({ }^{\circ} \mathrm{C}\right)$ & 18.0 & \multicolumn{2}{c}{16.6} \\
\hline
\end{tabular}

Symbols $\left({ }^{*}\right)$ indicate significant differences at $p \leq 0.05(*)$, or $0.001\left(^{* * *}\right)$.

The differences in morphological (Figure 4) and physiological (Table 2) traits observed among lighting regimes are the results of the action of photoreceptors, proteins which initiate plant responses to light [34]. Accordingly, plants react to variations in environmental lighting conditions (e.g., spectral composition, light intensity, and photoperiod) by converting light signal into biochemical responses, which may result in changes in plant morphology and physiology [27]. Besides, photoreceptors are also present in tomato fruits and may affect fruit development and ripening as described in the following section.

\subsection{LED Interlighting Enhances Fruit Growth and Yield Parameters}

Tomato fruit growth rate strongly depends on irradiation fluxes and distribution within the greenhouse environment [8]. In Jiang et al. [11], when greenhouse-grown tomato plants were supplied with supplemental LED interlighting, a 14\% increase of fresh yield as compared to control conditions was observed. However, yield response to lighting is highly related to the spectral features of the lamps used. For instance, supplementary lighting featuring either white or red LED spectra were proven more effective in fostering tomato fruit growth as compared with blue LEDs [8].

In the present research, fruit growth rate was monitored by measuring longitudinal and transversal fruit diameter during spring and summer season until harvesting time (Figure 5), resulting in larger fruits in LED treated plants as compared to those receiving sole solar radiation. At harvesting, longitudinal and transversal diameters were increased by $14 \%$ and $13 \%$, respectively during spring (Figure $5 \mathrm{a}, \mathrm{b}$ ) and by $5 \%$ and $6 \%$ during summer (Figure $5 \mathrm{c}, \mathrm{d}$ ). Apparently, supplemental LED interlighting improved light distribution within the canopy [10], which may have ultimately positively influenced tomato fruits growth especially during spring season, when the relative occurrence of days with lower radiation was higher than in summer (Figure 3c) [8].

Fruits ripening time was also influenced by LED supplemental lighting, resulting in a faster fruit growth and maturation in LED treated plants (Figure 6). On 29 April, when 91\% of fruits of LED treated plants were ready to harvest (dark orange and red colors) (Figure 6a), only $73 \%$ of fruits of control plants were at the same maturation stage (Figure $6 \mathrm{~b}$ ). The effect was also evident during the summer season, in which all fruits from LED treated plants were harvested two weeks earlier as compared to control plants (Figure $6 c, d$ ). From these results emerges that fruits ripening is influenced by changing in lighting conditions environment and is mediated by photoreceptors, as already observed by Gupta et al. [35] which, comparing the duration of ripening stage in two wild types of tomato plants and different phytochrome mutants (phyA, phyB1, phyB2, phyAB1, phyB1B2, and phyAB1B2), observed 
that mutant phyAB1B2 had most accelerated fruit ripening with fruit abscission nearly $21 \mathrm{~d}$ earlier than the wild types.

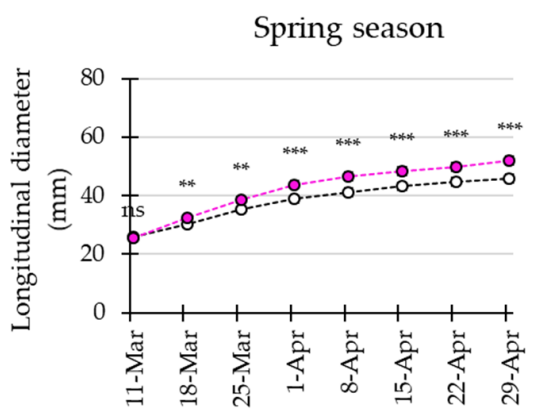

(a)

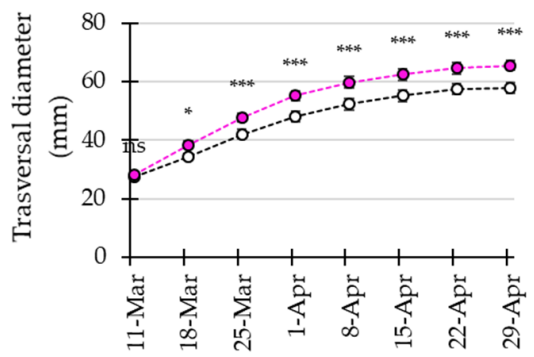

(b)

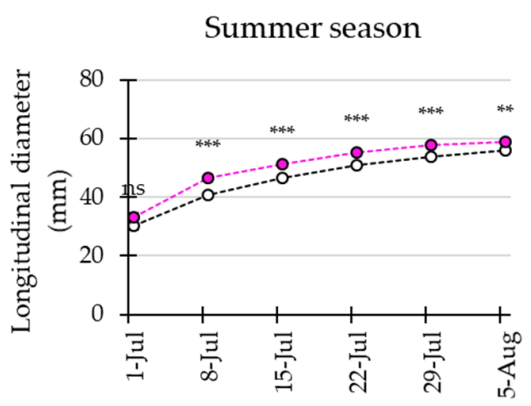

(c)

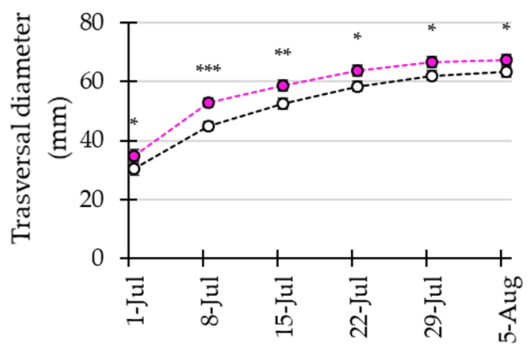

(d)

Figure 5. Effect of supplemental LED interlighting (pink) and control treatment (white) on longitudinal $(\mathbf{a}, \mathbf{c})$ and transversal diameter $(\mathbf{b}, \mathbf{d})$ during spring $(\mathbf{a}, \mathbf{b})$ and summer $(\mathbf{c}, \mathbf{d})$ season. Symbols $\left(^{*}\right)$ indicate significant differences at $p \leq 0.05\left(^{*}\right), 0.01\left(^{* *}\right)$, or $0.001\left({ }^{* * *}\right)$, "ns" indicates non-significant differences at $p \leq 0.05$.

The application of supplemental LED interlighting in tomato greenhouse cultivation was previously shown to increase crop productivity thanks to a higher light availability in regions where access to solar radiations may be limited [8-11]. However, no effects on yield could be associated with the exposition of cucumber and tomato to interlighting sources (e.g., HPS, fluorescent, and LED) in a number of other researches [36-38]. These contradictory results may be imputed to several causes, including among others reduced light interception in response to leaf curling, inefficient spectral composition of the supplemental light used or an extremely limited solar irradiance on the top of the canopy [38]. In the current study, yield $\left(\mathrm{kg} \mathrm{plant}^{-1}\right)$ of LED treated plants was higher as compared to control plants both in spring $(+24 \%)$ and summer $(+13 \%)$ season (Table 3). Similarly, supplemental LED interlighting starting from nighttime (from 4 a.m. to 4 p.m.) resulted in an increase of winter and summer productivity of $24 \%$ and $12 \%$, respectively as compared to the control in Japan [10]. Fruit number per plant was previously shown to be affected by the adoption of supplemental LED treatments [30,39]. However, in the present research, supplemental LED lighting did not affect fruit number (Table 3) and the observed increase in fruit yield should be linked to increased fruit size (Figure 5) and weight (Table 3) in both seasons. Accordingly, average fruit weight ( $\mathrm{g} \mathrm{fruit}^{-1}$ ) was enhanced by supplemental LED lighting by $16 \%$ and $15 \%$ during the spring and summer season, respectively, comparing to average fruit weight from control plants (Table 3$)$. Larger fruits $(+12 \%)$ in plants grown under supplemental LED lighting were previously associated to improved photosynthetic capacity [9]. Indeed, developing tomato fruit are also capable of photosynthesis and may contribute up to $20 \%$ to the fruit's photosynthate content, as formerly described by Hetherington et al. [40]. Accordingly, it could be advanced that photosynthesis in fruit could also be facilitated by LED light and resulted in more sustained fruit growth [41,42]. 


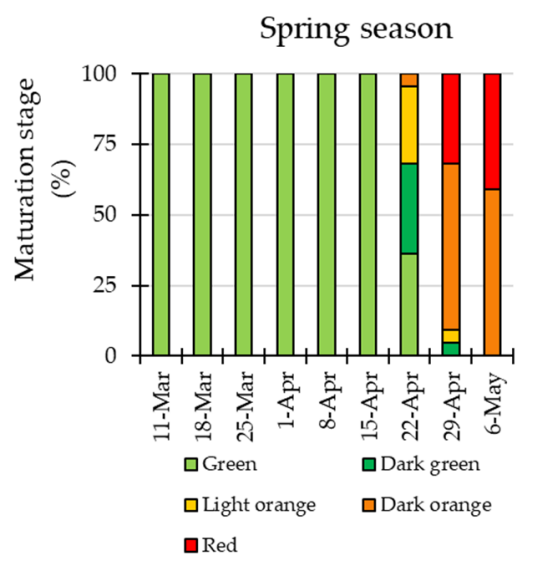

(a)

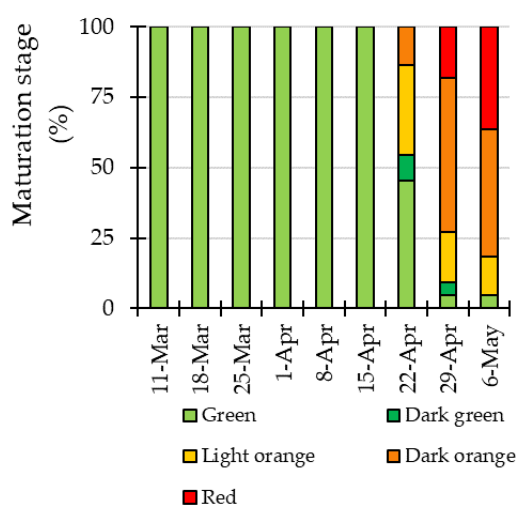

(b)

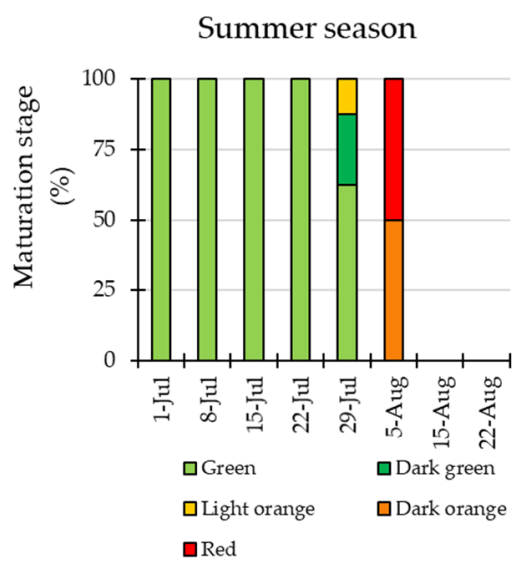

(c)

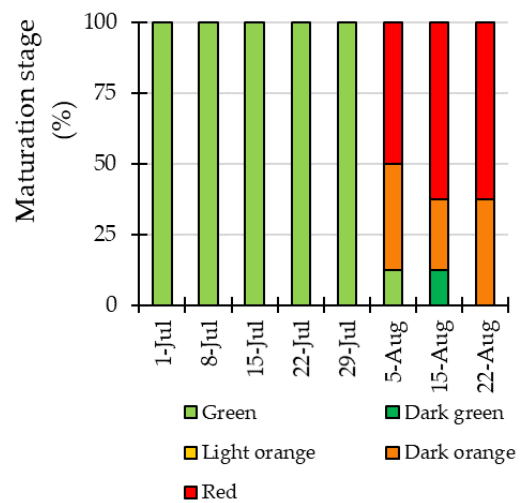

(d)

Figure 6. Effect of supplemental LED interlighting $(\mathbf{a}, \mathbf{c})$ and control treatment $(\mathbf{b}, \mathbf{d})$ on fruit growth/maturation stage during spring $(\mathbf{a}, \mathbf{b})$ and summer $(\mathbf{c}, \mathbf{d})$ season.

Table 3. Effect of lighting regime on plant productivity, fruit average weight, and fruit number during spring and summer season.

\begin{tabular}{|c|c|c|c|c|}
\hline & \multicolumn{2}{|c|}{ Spring } & \multicolumn{2}{|c|}{ Summer } \\
\hline & LED & Control & LED & Control \\
\hline Yield $\left(\mathrm{kg}\right.$ plant $\left.{ }^{-1}\right)$ & 5.7 & $\begin{array}{r}4.6 \\
* \quad\end{array}$ & 9.9 & $\begin{array}{r}8.8 \\
* \quad\end{array}$ \\
\hline Average fruit weight ( $\mathrm{g}$ fruit $^{-1}$ ) & 126.4 & ** 108.5 & 144.4 & ${ }_{* * *} 125.8$ \\
\hline Fruit number (n plant ${ }^{-1}$ ) & 45.0 & $n^{42.2}$ & 56.3 & ns ${ }^{57.1}$ \\
\hline
\end{tabular}

Symbols $\left({ }^{*}\right)$ indicate significant differences at $p \leq 0.05\left({ }^{*}\right), 0.01\left({ }^{* *}\right)$, or $0.001\left({ }^{* * *}\right)$, "ns" indicates non-significant differences at $p \leq 0.05$.

Cumulated total production $\left(\mathrm{kg} \mathrm{m}^{-2}\right)$ was enhanced by the supplemental LED lighting treatment (Figure 7). Under control conditions, the solar light extinction in the middle and lower portion of the canopy may substantially reduce crop yield in high-density greenhouses, especially during seasons when access to natural light may be limited [8]. Accordingly, in the present research, the beneficial effects on yield associated with the application of supplemental LED interlighting were maximized during spring, as compared with summer season. Overall, LED treated plants achieved a cumulated total productivity of $51 \mathrm{~kg} \mathrm{~m}^{-2}$, resulting in an increase of $16 \%$ as compared to control plants (Figure 7). 


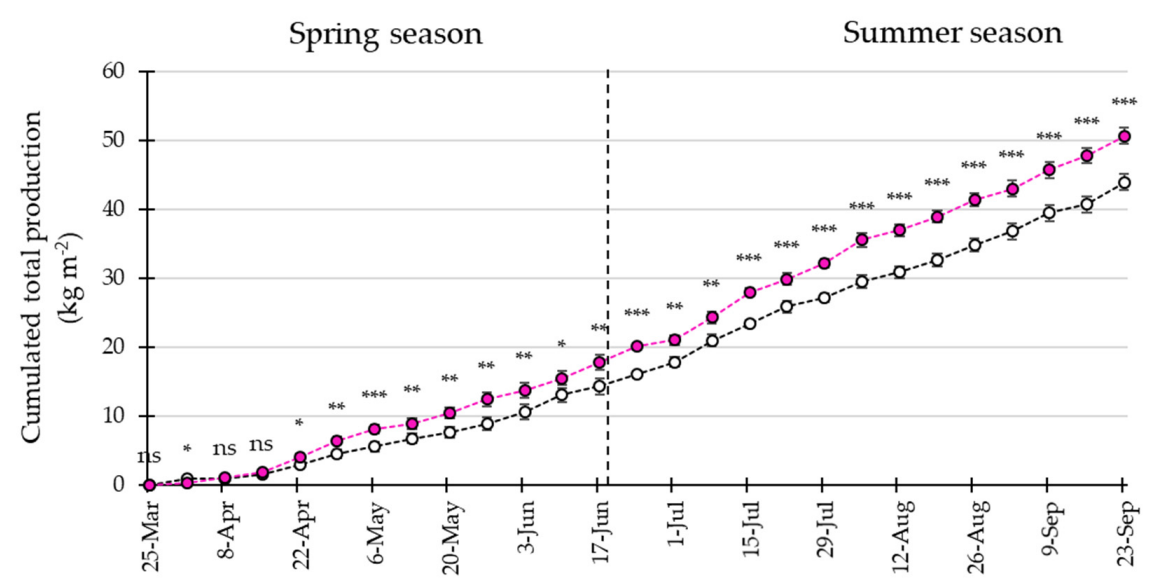

Figure 7. Effect of supplemental LED interlighting (pink) and control treatment (white) on the cumulated total production for spring and summer season. Symbols $\left(^{*}\right)$ indicate significant differences at $p \leq 0.05\left({ }^{*}\right), 0.01\left({ }^{* *}\right)$, or $0.001\left({ }^{* * *}\right)$, "ns" indicates non-significant differences at $p \leq 0.05$.

\subsection{Quality Parameters}

Content of soluble solids ( ${ }^{\circ}$ Brix) is a commonly adopted parameter to evaluate tomato fruit quality $[13,43,44]$. In Jiang et al. [11] the application of supplemental LED interlighting (emitting $200 \mu \mathrm{mol} \mathrm{m} \mathrm{m}^{-2} \mathrm{~s}^{-1}$ at $10 \mathrm{~cm}$ from $16 \mathrm{~h} \mathrm{~d}^{-1}$ ) significantly increased soluble solids content of tomato fruits by $16 \%$ as compared to control treatment without supplemental lighting. Similarly, Tewolde et al. [24] demonstrated that tomato plants under low-light stress conditions obtained using a cloudy cover simulation could compensate the decrease in total fruit soluble solids through the employment of supplemental LED interlighting, as compared to control treatment (no shading and no interlighting). However, the exposition of tomato plants to different LEDs colors (white, red, and blue LEDs, respectively) did not significantly alter the fruit sugar content as compared with plants grown under sole solar radiation [8]. Similarly, supplemental lighting treatment using LED towers (RB = 95:5, daily light integrals of $25 \mathrm{~mol} \mathrm{~m}^{-2} \mathrm{~d}^{-1}$ ) did not significantly influence fruit sugar content as compared to control-grown fruits [43]. In the hereby shown research, soluble solids content was not altered by lighting regimes (Table 4). Moreover, a CIE Lab analysis on harvested fruits was performed to assess final fruit color. Table 4 shows no significant differences for $\mathrm{L}$, $\mathrm{a}$, and $\mathrm{b}$ components. These results are consistent to those reported by Dzakovich et al. [43], where supplemental inner canopy LED towers did not affect the above-mentioned colorimetric indexes. Additionally, the a:b ratio whose correlation with lycopene content has been recently documented [44], was not influenced by supplemental LED interlighting, however, other lighting sources (e.g., supplemental overhead high-pressure sodium) could negatively affect this ratio [43]. Therefore, further research should specifically target a better understanding of fruit colorimetric response to the exposition to supplemental lighting.

Table 4. Effect of lighting regime on fruit soluble solids content and CIE Lab color space analysis.

\begin{tabular}{cccc}
\hline & LED & Control \\
\hline Soluble solids content $\left({ }^{\circ}\right.$ Brix $)$ & 3.7 & \multicolumn{2}{c}{3.9} \\
CIE Lab color space analysis & \multicolumn{3}{c}{ ns } \\
L & 41.3 & \multicolumn{2}{c}{42.4} \\
a & \multicolumn{2}{c}{ ns } & \\
b & 18.7 & \multicolumn{2}{c}{17.7} \\
a:b ratio & 21.6 & ns & 21.7 \\
& \multicolumn{2}{c}{0.87} & ns 0.81 \\
\hline
\end{tabular}

"ns" indicates non-significant differences at $p \leq 0.05$. 


\section{Conclusions}

Supplemental LED interlighting resulted in positive effects on plant morphology and fruit yield along spring and summer seasons of hydroponics tomato cultivation. The plant growth features were associated with improved leaf gas exchanges, which ultimately resulted in increased crop yield by means of larger fruit growth. Accordingly, the adoption of supplemental LED lighting may present interesting potentialities for improving cultivation performances in high-wire greenhouse-grown tomatoes in the Mediterranean area. Further research integrating a comprehensive financial analysis is needed in order to establish the economic feasibility of the proposed technology in the Mediterranean region. Moreover, future research should further investigate other qualitative aspects (e.g., carotenoid content, flavonoid content, and $\mathrm{pH}$ value), in order to have a better and overall understanding of supplemental LED interlighting effects on tomato quality in the Mediterranean area.

Author Contributions: Conceptualization, F.O., G.P., B.C., and G.G.; Methodology, F.O., G.P., A.C. (Andrea Crepaldi), and G.G.; Formal Analysis, I.P, A.P., A.C. (Antonio Cellini), and F.S.; Resources, A.C. (Andrea Crepaldi); Data Curation, G.P.; Writing-Original Draft Preparation, I.P., E.A., and G.P.; Writing-Review \& Editing, F.O., A.C. (Antonio Cellini), F.S, X.G., and G.G.; Visualization, G.P.; Supervision, F.O. and G.G. All authors have read and agreed to the published version of the manuscript.

Funding: This research received no external funding.

Conflicts of Interest: A. Crepaldi was employed by the company Flytech srl. The remaining authors declare no competing interests.

\section{References}

1. FAOSTAT. Food and Agriculture Organization Corporate Statistical Database. Available online: http: //www.fao.org/faostat/en/\#data/QC (accessed on 13 March 2020).

2. Jones, J.B., Jr. Tomato Plant Culture: In the Field, Greenhouse, and Home Garden, 2nd ed.; CRC Press: Boca Raton, FL, USA, 2007; p. 16.

3. Fernández, J.A.; Orsini, F.; Baeza, E.; Oztekin, G.B.; Muñoz, P.; Contreras, J.; Montero, J.I. Current trends in protected cultivation in Mediterranean climates. Eur. J. Hortic. Sci. 2018, 83, 294-305. [CrossRef]

4. Gómez, C. Light-Emitting Diodes as an Alternative Supplemental Lighting Source for Greenhouse Tomato Propagation and Production. Ph.D. Dissertation, Purdue University, Lafayette, LA, USA, November 2014.

5. De Pascale, S.; Orsini, F.; Caputo, R.; Palermo, M.A.; Barbieri, G.; Maggio, A. Seasonal and multiannual effects of salinisation on tomato yield and fruit quality. Funct. Plant Biol. 2012, 39, 689-698. [CrossRef] [PubMed]

6. De Pascale, S.; Maggio, A.; Orsini, F.; Stanghellini, C.; Heuvelink, E. Growth response and radiation use efficiency in tomato exposed to short-term and long-term salinized soils. Sci. Hortic. 2015, 189, 139-149. [CrossRef]

7. Lu, N.; Maruo, T.; Johkan, M.; Hohjo, M.; Tsukagoshi, S.; Ito, Y.; Ichimura, T.; Shinohara, Y. Effects of supplemental lighting within the canopy at different developing stages on tomato yield and quality of single-truss tomato plants grown at high density. Environ. Control Biol. 2012, 50,1-11. [CrossRef]

8. Lu, N.; Maruo, T.; Johkan, M.; Hohjo, M.; Tsukagoshi, S.; Ito, Y.; Ichimura, T.; Shinohara, Y. Effects of supplemental lighting with light-emitting diodes (LEDs) on tomato yield and quality of single-truss tomato plants grown at high planting density. Environ. Control Biol. 2012, 50, 63-74. [CrossRef]

9. Pepin, S.; Fortier, E.; Béchard-Dubé, S.A.; Dorais, M.; Ménard, C.; Bacon, R. Beneficial Effects of Using a 3-D LED Interlighting System for Organic Greenhouse Tomato Grown in Canada under Low Natural Light Conditions. Acta Hortic. 2014, 1041, 239-246. [CrossRef]

10. Tewolde, F.T.; Lu, N.; Shiina, K.; Maruo, T.; Takagaki, M.; Kozai, T.; Yamori, W. Nighttime Supplemental LED Inter-lighting Improves Growth and Yield of Single-Truss Tomatoes by Enhancing Photosynthesis in Both Winter and Summer. Front. Plant Sci. 2016, 7, 448. [CrossRef]

11. Jiang, C.; Johkan, M.; Hohjob, M.; Tsukagoshi, S.; Ebihara, M.; Nakaminami, A.; Maruo, T. Photosynthesis, plant growth, and fruit production of single-truss tomato improves with supplemental lighting provided from underneath or within the inner canopy. Sci. Hortic. 2017, 222, 221-229. [CrossRef]

12. Hao, X.; Little, C.; Zheng, J.M.; Cao, R. Far-red LEDs improve fruit production in greenhouse tomato grown under high-pressure sodium lighting. Acta Hortic. 2016, 1134, 95-102. [CrossRef] 
13. Park, Y.H.; Seo, B.S.; Seo, J.B.; Shin, G.H.; Yun, B.G. Effects of supplemental light on quality, yield, and growth rate of tomatoes. Acta Hortic. 2016, 1129, 105-110. [CrossRef]

14. Pan, T.; Ding, J.; Qin, G.; Wang, Y.; Xi, L.; Yang, J.; Li, L.; Zhang, J.; Zou, Z. Interaction of supplementary light and $\mathrm{CO}_{2}$ enrichment improves growth, photosynthesis, yield, and quality of tomato in autumn through spring greenhouse production. HortScience 2019, 54, 246-252. [CrossRef]

15. García-Caparros, P.; Chica, R.M.; Almansa, E.M.; Rull, A.; Rivas, L.A.; García-Buendía, A.; Barbero, F.J.; Lao, M.T. Comparisons of Different Lighting Systems for Horticultural Seedling Production Aimed at Energy Saving. Sustainability 2018, 10, 3351. [CrossRef]

16. Bantis, F.; Smirnakou, S.; Ouzounis, T.; Koukounaras, A.; Ntagkas, N.; Radoglou, K. Current status and recent achievements in the field of horticulture with the use of light-emitting diodes (LEDs). Sci. Hortic. 2018, 235, 437-451. [CrossRef]

17. Pennisi, G.; Blasioli, S.; Cellini, A.; Maia, L.; Crepaldi, A.; Braschi, I.; Spinelli, F.; Nicola, S.; Fernandez, J.A.; Stanghellini, C.; et al. Unravelling the role of red: Blue LED lights on resource use efficiency and nutritional properties of indoor grown sweet basil. Front. Plant Sci. 2019, 10, 305. [CrossRef] [PubMed]

18. Pennisi, G.; Orsini, F.; Blasioli, S.; Cellini, A.; Crepaldi, A.; Braschi, I.; Spinelli, F.; Nicola, S.; Fernandez, J.A.; Stanghellini, C.; et al. Resource use efficiency of indoor lettuce (Lactuca sativa L.) cultivation as affected by red: Blue ratio provided by LED lighting. Sci. Rep. 2019, 9, 1-11. [CrossRef]

19. Kittas, C.; Rigakis, N.; Katsoulas, N.; Bartzanas, T. Influence of shading screens on microclimate, growth and productivity of tomato. Acta Hortic. 2008, 807, 97-102. [CrossRef]

20. Jun, H.; Imai, K.; Suzuki, Y. Effects of day temperature on gas exchange characteristics in tomato ecotypes. Sci. Hortic. 1990, 42, 321-327. [CrossRef]

21. Kittas, C.; Katsoulas, N.; Bartzanas, T.; Bakker, S. Greenhouse climate control and energy use. In Good Agricultural Practices for Greenhouse Vegetable Crops: Principles for Mediterranean Climate Areas; Baudoin, W., Nono-Womdim, R., Lutaladio, N., Hodder, A., Castilla, N., Leonardi, C., De Pascale, S., Qaryouti, M., Eds.; FAO: Rome, Italy, 2013; Volume 217, pp. 63-95.

22. Shamshiri, R.R.; Jones, J.W.; Thorp, K.R.; Ahmad, D.; Man, H.C.; Taheri, S. Review of optimum temperature, humidity, and vapour pressure deficit for microclimate evaluation and control in greenhouse cultivation of tomato: A review. Int. Agrophys. 2018, 32, 287-302. [CrossRef]

23. Peet, M.M.; Welles, G. Greenhouse Tomato Production. In Tomatoes; Heuvelink, E., Ed.; CABI Publishing: Wallingford, UK, 2005; pp. 257-304.

24. Tewolde, F.T.; Shiina, K.; Maruo, T.; Takagaki, M.; Kozai, T.; Yamori, W. Supplemental LED inter-lighting compensates for a shortage of light for plant growth and yield under the lack of sunshine. PLoS ONE 2018, 13. [CrossRef]

25. Marcelis, L.F.M.; Broekhuijsen, A.G.M.; Meinen, E.; Nijs, E.M.F.M.; Raaphorst, M.G.M. Quantification of the growth response to light quantity of greenhouse grown crops. Acta Hortic. 2006, 711, 97-104. [CrossRef]

26. Hirose, T. Development of the Monsi-Saeki theory on canopy structure and function. Ann. Bot. 2005, 95, 483-494. [CrossRef] [PubMed]

27. Ménard, C.; Dorais, M.; Hovi, T.; Gosselin, A. Developmental and physiological responses of tomato and cucumber to additional blue light. Acta Hortic. 2006, 711, 291-296. [CrossRef]

28. Särkkä, L.E.; Jokinen, K.; Ottosen, C.O.; Kaukoranta, T. Effects of HPS and LED lighting on cucumber leaf photosynthesis, light quality penetration and temperature in the canopy, plant morphology and yield. AFSci 2017, 26, 102-110. [CrossRef]

29. Gajc-Wolska, J.; Kowalczyk, K.; Metera, A.; Mazur, K.; Bujalski, D.; Hemka, L. Effect of supplementary lighting on selected physiological parameters and yielding of tomato plants. Folia Hort. 2013, 25, 153-159. [CrossRef]

30. Gómez, C.; Mitchell, C.A. In search of an optimized supplemental lighting spectrum for greenhouse tomato production with intracanopy lighting. Acta Hortic. 2016, 1134, 57-62. [CrossRef]

31. XiaoYing, L.; ShiRong, G.; ZhiGang, X.; XueLei, J.; Tezuka, T. Regulation of chloroplast ultrastructure, cross-section anatomy of leaves, and morphology of stomata of cherry tomato by different light irradiations of light-emitting diodes. HortScience 2011, 46, 217-221. [CrossRef]

32. Pettersen, R.I.; Torre, S.; Gislerød, H.R. Effects of intracanopy lighting on photosynthetic characteristics in cucumber. Sci. Hortic. 2010, 125, 77-81. [CrossRef] 
33. Kotiranta, S. The Effect of Light Quality on Tomato (Solanum lycopersicum L. cv 'Efialto') Growth and DroughtTolerance. Master's Thesis, University of Helsinki, Helsinki, Finland, November 2014.

34. Mawphlang, O.I.; Kharshiing, E.V. Photoreceptor mediated plant growth responses: Implications for photoreceptor engineering toward improved performance in crops. Front. Plant Sci. 2017, 8, 1181. [CrossRef]

35. Gupta, S.K.; Sharma, S.; Santisree, P.; Kilambi, H.V.; Appenroth, K.; Sreelakshmi, Y.; Sharma, R. Complex and shifting interactions of phytochromes regulate fruit development in tomato. Plant. Cell Environ. 2014, 37, 1688-1702. [CrossRef]

36. Gunnlaugsson, E.; Adalsteinsson, S. Interlight and plant density in year-round production of tomato at northern latitudes. Acta Hortic. 2006, 711, 71-76. [CrossRef]

37. Heuvelink, E.; Bakker, M.J.; Hogendonk, L.; Janse, J.; Kaarsemaker, R.; Maaswinkel, R. Horticultural lighting in the Netherlands: New developments. Acta Hortic. 2006, 711, 25-34. [CrossRef]

38. Trouwborst, G.; Oosterkamp, J.; Hogewoning, S.W.; Harbinson, J.; Ieperen, W.V. The responses of light interception, photosynthesis and fruit yield of cucumber to LED-lighting within the canopy. Physiol. Plant. 2010, 138, 289-300. [CrossRef]

39. Gómez, C.; Mitchell, C.A. Physiological and Productivity Responses of High-wire Tomato as Affected by Supplemental Light Source and Distribution within the Canopy. J. Amer. Soc. Hort. Sci. 2016, 141, 196-208. [CrossRef]

40. Hetherington, S.; Smillie, R.; Davies, W. Photosynthetic activities of vegetative and fruiting tissues of tomato. J. Exp. Bot. 1998, 49, 1173-1181. [CrossRef]

41. Carrara, S.; Pardossi, A.; Soldatini, G.F.; Tognoni, F.; Guidi, L. Photosynthetic activity of ripening tomato fruit. Photosynthetica 2001, 39, 75-78. [CrossRef]

42. Matas, A.J.; Yeats, T.H.; Buda, G.J.; Zheng, Y.; Chatterjee, S.; Tohge, T.; Ponnala, L.; Adato, A.; Aharoni, A.; Stark, R.; et al. Tissue- and cell-type specific transcriptome profiling of expanding tomato fruit provides insights into metabolic and regulatory specialization and cuticle formation. Plant Cell 2011, 23, 3893-3910. [CrossRef] [PubMed]

43. Dzakovich, M.P.; Gómez, C.; Mitchell, C.A. Tomatoes grown with light-emitting diodes or high-pressure sodium supplemental lights have similar fruit-quality attributes. HortScience 2015, 50, 1498-1502. [CrossRef]

44. Helyes, L.; Pék, Z.; Lugasi, A. Tomato fruit quality and content depend on stage of maturity. HortScience 2006, 41, 1400-1401. [CrossRef]

(C) 2020 by the authors. Licensee MDPI, Basel, Switzerland. This article is an open access article distributed under the terms and conditions of the Creative Commons Attribution (CC BY) license (http://creativecommons.org/licenses/by/4.0/). 